\title{
Sugar Spectrum, Hydroxymethylfurfural and Diastase Activity in Honey: A Validated Approach as Indicator of Possible Adulteration
}

\author{
Victoriţa BONTA ${ }^{1}$, Daniel Severus DEZMIREAN² ${ }^{2}$ Liviu Alexandru MĂRGHITAȘ², \\ Adriana Cristina URCAN ${ }^{3}$, Otilia BOBIŞ ${ }^{*}$ \\ ${ }^{1}$ Life Science Institute "Michael I of Romania", University of Agricultural Sciences and Veterinary Medicine \\ Cluj-Napoca, Romania. \\ ${ }^{2}$ Department of Apiculture and Sericulture, Faculty of Animal Science and Biotechnology, University of \\ Agricultural Sciences and Veterinary Medicine Cluj-Napoca, Romania. \\ ${ }^{3}$ Department of Microbiology, Faculty of Animal Science and Biotechnology, University of Agricultural \\ Sciences and Veterinary Medicine Cluj-Napoca, Romania. \\ *corresponding author, e-mail: obobis@usamvcluj.ro
}

Bulletin UASVM Animal Science and Biotechnologies 77(2)/2020

ISSN-L 1843-5262; Print ISSN 1843-5262; Electronic ISSN 1843-536X

DOI:10.15835/buasvmcn-asb: 2020.0008

\begin{abstract}
Honey is used for centuries both as nutrient and in medicine, being an exhaustless source of benefic factors for health and also for different biotechnological processes. This is a complex matrix which possesses antioxidant and antimicrobial properties due to its peroxidic activity and bioactive compounds. A fully validated approach for the determination of sugars, hydroxymethylfurfural content and diastase activity in honey samples were presented in accordance with the official methods from the International Honey Commission. Spectrophotometric method was used for diastazic activity determination and chromatographic determinations for HMF content (photodiode array detection) and sugars (refractive index detection). The limits of detection and quantification were calculated. Accuracy, precision and uncertainty were determined in the spectrophotometric and chromatographic techniques using the certified reference material. Diastase activity, sucrose content and hydroxymethylfurfural (HMF) content were easily differentiated and these parameters were used for indication of a possible adulteration of the honey. The present study confirms that, in order to have an authentic honey sample, diastazic activity must be above 8 DN (diastazic number) and HMF content less than $40 \mathrm{mg} / \mathrm{kg}$. Sugar spectrum is different for every honey type. Consequently, physico-chemical analysis should be combined for the determination of authentic honey and proper labeling.
\end{abstract}

Keywords: authenticity, diastase activity, honey, hydroxymethilfurfural, sugar spectrum.

\section{Introduction}

Honey is "a natural sweet substance produced by the honey bees Apis mellifera from the nectar of plants or from secretions of living parts of plants or excretions of plant-sucking insects on the living parts of plants, which the bees collect, transform by combining with specific substances of their own, deposit, dehydrate, store and leave in the honey comb to ripen and mature", as stated by Directive 2014/63/EU. In fact, honey is a very complex mixture of sugars and water (as major components) and a multitude of substances (vitamins, minerals, proteins, amino acids, organic acids, hydroxymethylfurfural, antioxidants from 
the class of phenolic acids and flavonoids and different enzymes) as minor components.

Beside its nutritional value, honey possess a wide range of bioactive properties, due to its complex chemical composition: antioxidant, antibacterial, hypoglycemic, antifungal, gastroprotective, anti-inflammatory effects (Alvarez-Suarez et al., 2013; Vallianou et al., 2014; Machado De-Melo et al., 2017; Scepankova et al., 2017; Soares et al., 2017; Bobiş et al. 2018; Fazalda et al., 2018). The importance of honey in human nutrition is obvious, and studied since early times, nowadays the modern methods used for chemical composition determination and also high resolution equipments, responded to the questions raised over the time (Oroian \& Ropciuc, 2019; Bobiș et al., 2020; Geana \& Ciucure, 2020; Pauliuc et al., 2020). Beside this, it is demonstrated that different types of honey possess many healing properties, first against reactive oxygen species, which are the principal responsible for different diseases, many of them being considered deadly of with low chances of curing (Alvarez-Suarez et al. 2016; Afrin et al., 2019; Kocyigit et al., 2019). The apoptotic effect of honey or it's extracts on different carcinoma cells is also demonstrated in a series of scientific studies (Samarghandian et al., 2011; Morales \& Haza, 2013; Rady et al., 2018).

Similar to other food products, honey may be subjected to possible adulteration. Two aspects should be considered when talking abour honey authenticity: authenticity related to production and processing and authenticity related to description (Mădaș et al., 2019a; Geana et al., 2020). Honey chemical composition determination, comprises physico-chemical determinations, spectrophotometric and chromatographic methods, sensory analysis and palynological determinations of uniflorality (Mădaş et al., 2019b).

Sugar profile in honey vary due to its botanical origin. Although glucose and fructose are the most important sugars in honey, their quantity and ratio, may give informations about botanical origin of honey (Mărghitaş et al., 2010; Kamal and Klein, 2011; Aronne et al., 2014; Mădaş et al., 2019b; Vranic et al., 2019). Also, the presence of different minor sugars are used as potential markers for different types of honey (Sanz et al., 2005; Pereira et al., 2014). Honey is different from other natural sweetners, by the presence of enzymes. Naturally, honey contain small amounts of enzymes. They are added by the bees, but may came from the nectar of the floral source. The predominant enzymes in honey are diastase, invertase and glucose oxidase (Bogdanov et al., 2008). Diastase (or amylase) is an important indicator of honey freshness and authenticity (Persano-Oddo et al., 1990; AlvarezSuarez et al., 2013). It came from the bees in the process of transforming the nectar into honey. The nectar type and flow, and the age of the bees are the main factors for the amount of diastase found in honey (Persano-Oddo et al., 1990). Invertase degrades sucrose in more simple constituents, the reason why in honey different minor sugars are present, although they are not present in nectar (Donner, 1977). Invertase is present in ripen honey, and may be determined spectrophotometrically (Persano-Oddo et al., 1999). Glucose oxidase (GOx) is an important enzyme of honey, directly related to the antibacterial activity of honey. This enzyme is degrading glucose to a gluconolactone and further to gluconic acid (the main organic acid in honey) and hydrogen peroxide, the main substance responsible for the antibacterial activity. The enzyme was found in the hypopharyngeal gland of the bees, from where it reaches honey (Bucekova et al., 2014). Hydroxymethilfurfural (HMF) is a furane compound, generally formed in the caramelisation process (thermal treatment applied on carbohydrate containing products). The presence of simple sugars and different acids in honey, combined with high temperature storage or procession, lead to the appearance of high amounts of HMF, which may be found in very small amounts even in fresh honey. Codex Alimentarius Standard Commision have stated a limit of $40 \mathrm{mg} /$ $\mathrm{kg}(80 \mathrm{mg} / \mathrm{kg}$ for honeys from Tropical regions), which permit moderate heationg of honey to have a lower amount of HMF present in commercial honey properly processed (Codex Alimentarius, 2001).

In order to have a guarantee that such methods may be used as indicators for honey authenticity, their validation is required. Laboratory for Quality Control of Bee Products have validated internally the above mentioned methods according to Eurachem CITAC Guide (2012; 2019) and with proficiency testing participations.

\section{Materials and methods}

The research has been carried out in Laboratory for Quality Control of Bee Products and Bee 
Diseases from University of Agricultural Sciences and Veterinary Medicine Cluj-Napoca, Romania.

Honey samples. Twenty-four honey samples of different botanical and geographical origins (5 samples of acacia honey, 3 polifloral, 4 rape (canola), 3 honeydews, 2 buckwheat, 2 sunflowers, one of linden, raspberry and heather from Romania and also one sample of eucalyptus and lavender from the Proficiency Testing Trial). All honeys were melisopalynologically characterized, and their botanical origin was established according to the validated method used in our laboratory (Louvreaux et al., 1978).

Sugar spectrum determination. Sugar content determination in the laboratory is made according to European Honey Commision (1997) Method, using high performance liquid chromatography and refractive index detection for principal sugars present in honey (Bonta et al. 2008). The HPLC analysis of the carbohydrates is carried out on a modified Alltima Amino $100 \AA$ stainless steel column ( $4.6 \mathrm{~mm}$ diameter, $250 \mathrm{~mm}$ length, particle size $5 \mu \mathrm{m}$ ). The SHIMADZU instrument (LC-10AD VP model, Shimadzu, Kyoto, Japan) is equipped with degasser, two pumps, auto sampler, thermostat oven, controller and refractive index detector. The injection volume was $10 \mu \mathrm{l}$ and the flow rate was $1.3 \mathrm{ml} / \mathrm{min}$. The mobile phase is a solution of HPLC purity acetonitrile and ultrapure water $(80 / 20 \mathrm{v} / \mathrm{v})$. Five $\mathrm{g}$ of honey are dissolved in water $(40 \mathrm{ml})$ and transferred into a $50 \mathrm{ml}$ volumetric flask, containing $12 \mathrm{ml}$ HPLC grade purity methanol and filled up to the mark with water. The solution is filtered through a 0.45 $\mu \mathrm{m}$ membrane filter, collected in sample vials and placed in autosampler for analysis. For the quantification of main sugars, different calibration curves in the range 50-0.25 g/100 g (fructose 50$20 \mathrm{~g} / 100 \mathrm{~g}$; glucose 10-40 g/100 g; sucrose 0.3$15 \mathrm{~g} / 100 \mathrm{~g}$; turanose, maltose, isomaltose, erlose $0.25-5 \mathrm{~g} / 100 \mathrm{~g})$, with regression coeffcients $\left(\mathrm{R}^{2}\right)$ higher of 0.998 were obtained. The results are expressed in $\mathrm{g} / 100 \mathrm{~g}$ honey.

Diastase activity. Diastase activity is determined following the protocol of Megazyme International Ireland (2014) and validated in the lab. Two g of honey are weighted and dissolved in 40 $\mathrm{ml}$ maleat buffer $100 \mathrm{mM}$ (pH 5.6) in a beaker and transferred quantitatively in a $50 \mathrm{ml}$ volumetric flask. $1 \mathrm{ml}$ of the diluted honey is placed in a glass tube and is pre-incubated at $40^{\circ} \mathrm{C}$ for $5 \mathrm{~min}$.
An Amylazyme tablet is added to the tube, without removing from the water bath and without stirring. The incubation is continued for another $10 \mathrm{~min} .10 \mathrm{ml}$ of Trizma base solution is added to terminate the reaction and the tube is stirred on a vortex for about $30 \mathrm{sec}$. After $5 \mathrm{~min}$ at room temperature, the solution is filtered through filter paper and the absorbance is read against a reaction blank (prepared in the same way, except adding the sample). For a lot of Amylazyme tablets (200 pcs) a calibration curve is provided by the beneficiary. For the analysed honey samples presented in this study, the diastase activity was calculated following the equation:

$$
\text { Diastazic activity }=20 \times \mathrm{DO}_{590}
$$

HMF analysis. HMF determination was based on the method described by the European Honey Commision (1997) and validated in the lab. HMF is determined from a clear, filtered aqueous solution of honey, using high performance liquid chromatogtaphy with photodiode array detection, where the signal is compared with a standard of known concentration. The separation is made on a Discovery HS C18 ( $5 \mu \mathrm{m}$; 4.6x250 mm) column, equipped with a C18 pre-column, mobile phases: ultrapure water (solvent A) and HPLC grade methanol (solvent B), injection volume $20 \mu \mathrm{l}$ and $0.8 \mathrm{ml} / \mathrm{min}$ flow rate in gradient mode. The gradient started at $10 \%$ B until 13 min, increase to $90 \%$ B at 15 min and run isocratically (90\% B) up to $20 \mathrm{~min}$. The percent B decreased to $10 \% \mathrm{~B}$ and runs $10 \mathrm{~min}$ at the same concentration. The detection is made at $283 \mathrm{~nm}$. Ten grams of honey is weighted in a glass beaker and approx $25 \mathrm{ml}$ water is added for dissolution. The honey solution is transferred to a $50 \mathrm{ml}$ volumetric flask, and $0.5 \mathrm{ml}$ Carrez I solution is added. After proper mixing, 0.5 $\mathrm{ml}$ Carrez II solution is added and filled to the sign with water. After mixing all reagents, the solution is filtered through filter paper and the first 10 $\mathrm{ml}$ are discharged. The solution is again filtered through Millipore filter $(0.45 \mu \mathrm{m})$ and injected into HPLC system. A calibration curve is constructed with known concentration of HMF standard, subjected to the same preparation protocol as the sample and the unknown concentration of HMF from honey samples are determined using the calibration curve values. The result is expressed as $\mathrm{mg} \mathrm{HMF} / \mathrm{kg}$ honey. 
Method validations. Honey is a complex matrix, different from one sample to another. Because the validation of an analytical method need a reference material, an in house reference material was used, a honey with all parameters determined, divided into small amounts and kept in the freezer. The reference material was used to determine the limit of detection (LOD), limit of quantification (LOQ). In house reference material was used for accuracy, precision and uncertainty of the proposed methods, following Eurachem/CITAC Guidelines (2012, 2019). Limit of detection is the lowest concentration of analyte that can be determined with confidence. For the determination of LOD, 7 independent standard solutions of fructose, glucose and sucrose in mixture, were measured (repeatability level $0.1 \%$ ). The average concentration for each sugar and standard deviation of the 7 determinations was calculated. LOD was expressed as "c+3STDEV". The limit of quantification (LOQ) is strictly, the lowest analyte concentration that can be determined with an acceptance level of fidelity or repeatability and accuracy. 7 independent standard solutions of fructose, glucose and sucrose in mixture were measure under repeatability conditions, each measured once (concentration level $0.1 \%$ ). The average concentrations and standard deviation of the 7 determinations were calculated. The LOQ was expressed as having the value of "c+10STDEV". Precision was studied by repeatability (the results of independent tests were obtained by the same method, from the same honey sample, in the same laboratory, by the same operator using the same equipment, in short intervals) and reproducibility (the results of independent tests were obtained with the same method, from the same honey sample, in the same laboratory, but by different analysts under different conditions, on different days). Established performance criteria: the relative standard deviation of the value of determinant, measured under repeatability conditions should not exceed 5\%. Accuracy expresses the degree of agreement (approximation) between the average value obtained in a series of test results and a reference value (true value). It is ideal to compare the analytical result with a certified value. Established performance criteria: accuracy expressed as the relative difference between the average of 6 determinations and the actual (reference) value should not exceed $5 \%$. Uncertainty is a parameter associated with the result of a measurement, which characterizes the dispersion of values that can reasonably be assigned to the measurement. Uncertainty was calculated for a $95 \%$ confidence interval and a coverage factor of $\mathrm{k}=2$. Established performance criteria: extended uncertainty should not exceed $20 \%$ of the measurement value.

Same validation parameters were made for HMF determination: LOD, LOQ accuracy, precision and uncertainty, following Eurachem/CITAC Guidelines (2012, 2019). Diastase validation followed uncertainty, accuracy and precision determinations, similar to sugars and hydroximethilfurfural determination.

\section{Results and discussions}

Method validation results. Detection and quantitation limits (LOD and LOQ) were determined on reference materials (standards of HMF and sugars). Average value of the seven measurements was determined $(0.117 \mathrm{mg} / \mathrm{L}$ HMF) and relative standard deviation (0.0095). LOD was expressed using the formula: c+3STDEV. Obtained value was $0.15 \mathrm{mg} / \mathrm{L}$ (the lowest concentration which may be determined with confidence). For LOQ determination, the same 7 determinations were used, with the same values of the mean and standard deviation. The value obtained for LOQ was $0.21 \mathrm{mg} / \mathrm{L}$. Established performance criteria: $\mathrm{LOD}<\mathrm{LOQ}<$ the lowest value from the work concentrations domain. LOD and LOQ determination for individual sugars (fructose, glucose and sucrose), a mixture of the three sugars was made, $0.1 \%$ each, following the described method. The LOD values were: fructose $0.13 \%$; glucose $0.13 \%$; sucrose $0.15 \%$, and LOQ values were: fructose $0.22 \%$; glucose $0.23 \%$; sucrose $0.22 \%$.

Precision was studied by repeatability and reproducibility determinations, taking into analysis three in house reference materials with different levels of HMF concentration. The average value of the 6 measurements was: $3.38,15.99$ and $42.43 \mathrm{mg} / \mathrm{kg}$. Relative standard deviation (\%RSD) was calculated for every concentration level, and 2.11, 1.80 and $1.85 \%$ was obtained. Under reproducibility conditions, values of $8.51,7.79$ and $4.94 \%$ were obtained, which must be lower than 10\% (Eurachem Citac 
Table 1. Uncertainty calculated for the three parameters (sugars, diastase and HMF) in APHIS Laboratory

\begin{tabular}{cccc}
\hline Level of concentration & $\mathrm{U}$ & Calculated result & $\mathrm{U} \cdot 100 / \mathrm{c}(\%)$ \\
\hline Sugars $\mathbf{( g / 1 0 0 g )}$ & & & 4.81 \\
\hline Fructose: 41.20 & 1.98 & $\mathrm{C}_{\text {fructose }}=41.20 \pm 1.98 \mathrm{~g} / 100 \mathrm{~g}$ honey & 6.43 \\
\hline Glucose: 25.82 & 1.66 & $\mathrm{C}_{\text {glucose }}=25.82 \pm 1.66 \mathrm{~g} / 100 \mathrm{~g}$ honey & 18.25 \\
\hline Sucrose: 1.37 & 0.25 & $\mathrm{C}_{\text {sucrose }}=1.37 \pm 0.25 \mathrm{~g} / 100 \mathrm{~g}$ honey & \\
\hline Diastase (SU) & & & 6.69 \\
\hline Level : 7.17 & 0.48 & $7.17 \pm 0.48$ Shade units $/ \mathrm{g}$ & 17.63 \\
\hline Level : 12.42 & 2.19 & $12.42 \pm 2.19$ Shade units $/ \mathrm{g}$ & 7.69 \\
\hline Level : 22.49 & 1.73 & $22.49 \pm 1.73$ Shade units $/ \mathrm{g}$ & 18.67 \\
\hline HMF (mg/kg) & & & 17.10 \\
\hline Level : 3.38 & 0.63 & $\mathrm{C}_{\mathrm{HMF}}=3.38 \pm 0.63 \mathrm{mg} / \mathrm{kg}$ & 12.15 \\
\hline Level : 15.9 & 2.71 & $\mathrm{C}_{\mathrm{HMF}}=15.9 \pm 2.71 \mathrm{mg} / \mathrm{kg}$ &
\end{tabular}

U-extended uncertainity.

Table 2. The chemical composition of analysed honey samples

\begin{tabular}{lccl}
\hline \multicolumn{1}{c}{ Honey type } & HMF $(\mathrm{mg} / \mathrm{kg})$ & Diastazic index & \multicolumn{1}{c}{ Palynological analysis } \\
\hline Acacia 1 & 1.5 & 2.8 & $<20 \%$ acacia pollen \\
\hline Acacia 2 & 3.1 & 2.5 & $30.6 \%$ acacia pollen \\
\hline Acacia 3 & 5.9 & 8.9 & rape and Graminee pollen \\
\hline Acacia 4 & 7.0 & 8.4 & multifloral pollen \\
\hline Acacia 5 & 0.6 & 6.0 & $18.4 \%$ acacia pollen \\
\hline Multifloral 1 & 3.1 & 4.6 & - \\
\hline Multifloral 2 & 1.2 & 10.8 & - \\
\hline Multifloral 3 & 6.7 & 2.8 & - \\
\hline Rape 1 & 4.4 & 8.1 & $>30 \%$ rape pollen \\
\hline Rape 2 & 4.8 & 7.4 & $>30 \%$ rape pollen \\
\hline Rape 3 & 10.2 & 9.4 & $>30 \%$ rape pollen \\
\hline Rape 4 & 1.7 & 9.7 & $>30 \%$ rape pollen \\
\hline Honeydew 1 & 17.7 & 10.4 & honeydew elements present \\
\hline Honeydew 2 & 4.1 & 9.2 & honeydew elements present \\
\hline Honeydew 3 & 0.8 & 10.7 & honeydew elements present \\
\hline Linden & 7.8 & 9.0 & $>30 \%$ linden pollen \\
\hline Sunflower 1 & 2.4 & 7.5 & $>40 \%$ sunflower pollen \\
\hline Sunflower 2 & 14.0 & 6.1 & $>40 \%$ \\
\hline Raspberry & 13.9 & 9.5 & $>25 \%$ raspberry pollen \\
\hline Buckwheat & 22.1 & 5.2 & buckwheat pollen present \\
\hline Buckwheat & 4.7 & 10.0 & buckwheat pollen present \\
\hline Heather & 1.3 & 57.4 & heather pollen present \\
\hline Eucalyptus & 45.8 & 4.7 & $>60 \%$ eucalyptus pollen \\
\hline Lavander & 40.4 & 7.7 & lavender pollen present \\
\hline
\end{tabular}


Guide, 2000). For sugars and diastase method validation, the same protocol was followed, and lower \%RSD values that $5 \%$ were obtained in the case of repeatability and lower that $10 \%$ for reproducibility.

Due to the lack of certified material (honey), we took an in house reference material with known HMF value $(3.38 \mathrm{mg} / \mathrm{kg})$ and a fortification with another $3.3 \mathrm{mg} / \mathrm{kg}$ and $20 \mathrm{mg} / \mathrm{kg}$ HMF standard were made. Average value concentration, following 6 time determinations was $6.65 \mathrm{mg} / \mathrm{kg}$ and 23.32 $\mathrm{mg} / \mathrm{kg}$. Recovery percent was determined and values of $97.42 \%$ for the first fortification level and $99.70 \%$ for the second fortification level. The established performance criteria (recovery percent $90-100 \%$ and $\% \mathrm{RSD}<5 \%$ ) was obtained. Recovery values for sugars were determined, and $101.8 \%$ (fructose), $99.7 \%$ (glucose) and 100.6\% sucrose were obtained.

The uncertainty was determined on in house reference material, having the concentrations of sugars, HMF and diastase shown in Table 1 (Level of concentration), following Eurachem Citac Guide (2000).

Extended uncertainty was calculated for a confidence interval of $95 \%$ and covering factor $\mathrm{k}=2$. Established performance criteria was accomplished, extended uncertainty (U), did not exceed $20 \%$ from the measured value.

Analysed samples results. Twenty-four honey samples (5 samples of acacia honey, 3 polifloral,
4 rape (canola), 3 honeydews, 2 buckwheat, 2 sunflowers, one of linden, raspberry and heather from Romania and also one sample of eucalyptus and lavender from the Proficiency Testing Trial) were subjected to chemical analysis of sugars, diastase activity and hydroxymethilfurfural content. Before chemical composition analysis, palynological determinations were made to confirm or not the declared botanical origin (Table 2) for the unifloral declared honey samples.

HMF and diastase were determined following the accreditated methods presented in previous section. Romanian honey samples presented HMF content within the national and international regulations $(<40 \mathrm{mg} / \mathrm{kg})$, with values ranging from 0.6 to $22.1 \mathrm{mg} / \mathrm{kg}$, depending on the botanical origin of each honey. Regarding eucalyptus and lavender honeys, the background is unknown, samples being shipped from France in the Proficiency Test Trial of the laboratory, but from the other physicochemical and sensorial analysis, resulting a probable heating of the sample (Figure 1).

Diastase index is a parameter showing the "involvement" of the bee in the process of transforming the nectar into honey. National standard regulations state a minimum diastazic index value of 6.5 in the case of Acacia honey, 10.9-13.9 for honeydew and other honey types a minimum of 10.9 units, in order to declare a sample as authentic honey. The analyzed samples presented a wide range of values, and for this reason other differ-

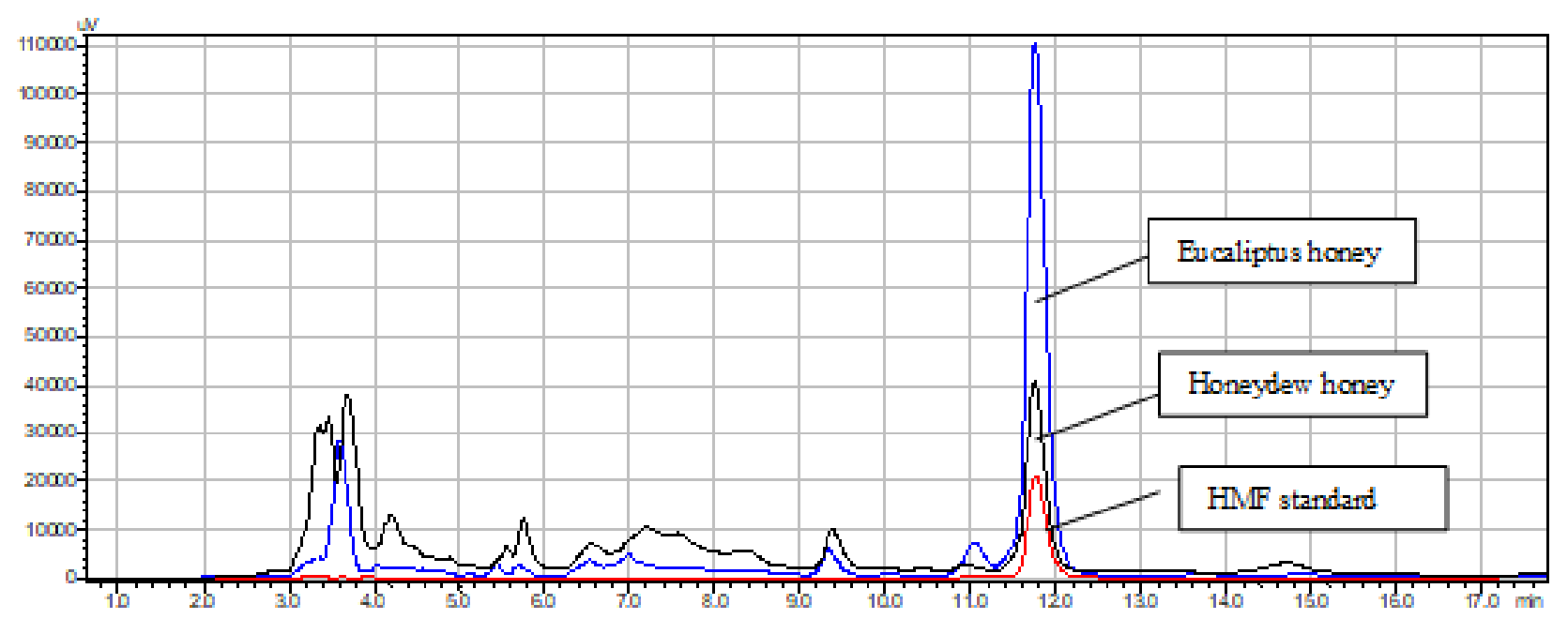

Figure 1. Overlapped chromatogram of HMF standard (2 mg/L), honeydew honey $(17.7 \mathrm{mg} / \mathrm{kg})$ and eucalyptus honey $(45.8 \mathrm{mg} / \mathrm{kg})$ 
ent methods are needed to determine the authenticity. Some of Acacia honey samples, have lower diastazic values than the minimum admitted by the standard, but if Council Directive 2001/110 or Codex Standard for Honey (2001) is taking into account, minimum limit of 3 units is accepted for low natural diastase content honeys, and HMF content not higher than $15 \mathrm{mg} / \mathrm{kg}$.

Sugar spectrum is registered as a chromatogram by the HPLC system (Figure 2). The results obtained for all honeys are presented in Table 3. The first two acacia samples, have indeed the $\mathrm{F} / \mathrm{G}$ ratio higher than 1.2 , and correlated with palynological origin, show that the samples are monofloral acacia samples. The other two, have higher amounts of glucose, and also the palynological analysis did not reveal acacia pollen in the sediment, so they can't be classified as acacia. The last declared acacia sample have a very high amount of sucrose, much more than the maximum limit. Here we can suppose a possible falsification. One of the multifloral samples have also high sucrose content. Regarding honeydew honeys, the presence of melezitose was investigated (data not shown). The presence of this tri- saccharide, in two of three samples, correlated with the presence of honeydew elements and high electrical conductivity (data not shown), were enough to classify the samples as honeydew honeys.

Table 3. HPLC determination of sugar spectrum for the analysed honey samples

\begin{tabular}{lcccc}
\hline \multicolumn{1}{c}{ Honey type } & Fructose $(\%)$ & Glucose $(\%)$ & Sucrose $(\%)$ & F/G ratio \\
\hline Acacia 1 & 41.65 & 24.84 & 3.38 & 1.68 \\
\hline Acacia 2 & 44.16 & 26.76 & 0.78 & 1.65 \\
\hline Acacia 3 & 41.97 & 32.36 & 0.60 & 1.30 \\
\hline Acacia 4 & 40.19 & 37.73 & 0.03 & 1.07 \\
\hline Acacia 5 & 30.74 & 27.11 & 14.84 & 1.13 \\
\hline Multifloral 1 & 39.02 & 26.58 & 1.15 & 1.47 \\
\hline Multifloral 2 & 36.7 & 26.08 & 6.59 & 1.41 \\
\hline Multifloral 3 & 33.47 & 34.46 & 11.44 & 0.97 \\
\hline Rape 1 & 36.71 & 41.86 & $\mathrm{Nd}$ & 0.88 \\
\hline Rape 2 & 36.98 & 42.30 & $\mathrm{Nd}$ & 0.87 \\
\hline Rape 3 & 36.15 & 38.96 & $\mathrm{Nd}$ & 0.93 \\
\hline Rape 4 & 39.1 & 39.9 & $\mathrm{Nd}$ & 0.98 \\
\hline Honeydew 1 & 38.40 & 27.13 & 0.06 & 1.42 \\
\hline Honeydew 2 & 39.08 & 30.76 & 0.98 & 1.27 \\
\hline Honeydew 3 & 33.98 & 26.16 & $\mathrm{Nd}$ & 1.30 \\
\hline Linden & 36.21 & 33.01 & 0.06 & 1.10 \\
\hline Sunflower 1 & 38.74 & 40.42 & $\mathrm{Nd}$ & 0.96 \\
\hline Sunflower 2 & 38.69 & 35.87 & 0.05 & 1.08 \\
\hline Raspberry & 42.84 & 27.74 & 0.07 & 1.54 \\
\hline Buckwheat & 36.93 & 36.90 & $\mathrm{Nd}$ & 1.00 \\
\hline Buckwheat & 37.51 & 30.11 & 0.41 & 1.18 \\
\hline Heather & 39.65 & 33.44 & 0.03 & \\
\hline Eucalyptus & 38.77 & & & 1.81 \\
\hline Lavander & 37.96 & & & \\
\hline & & 32.11 & & \\
\hline
\end{tabular}



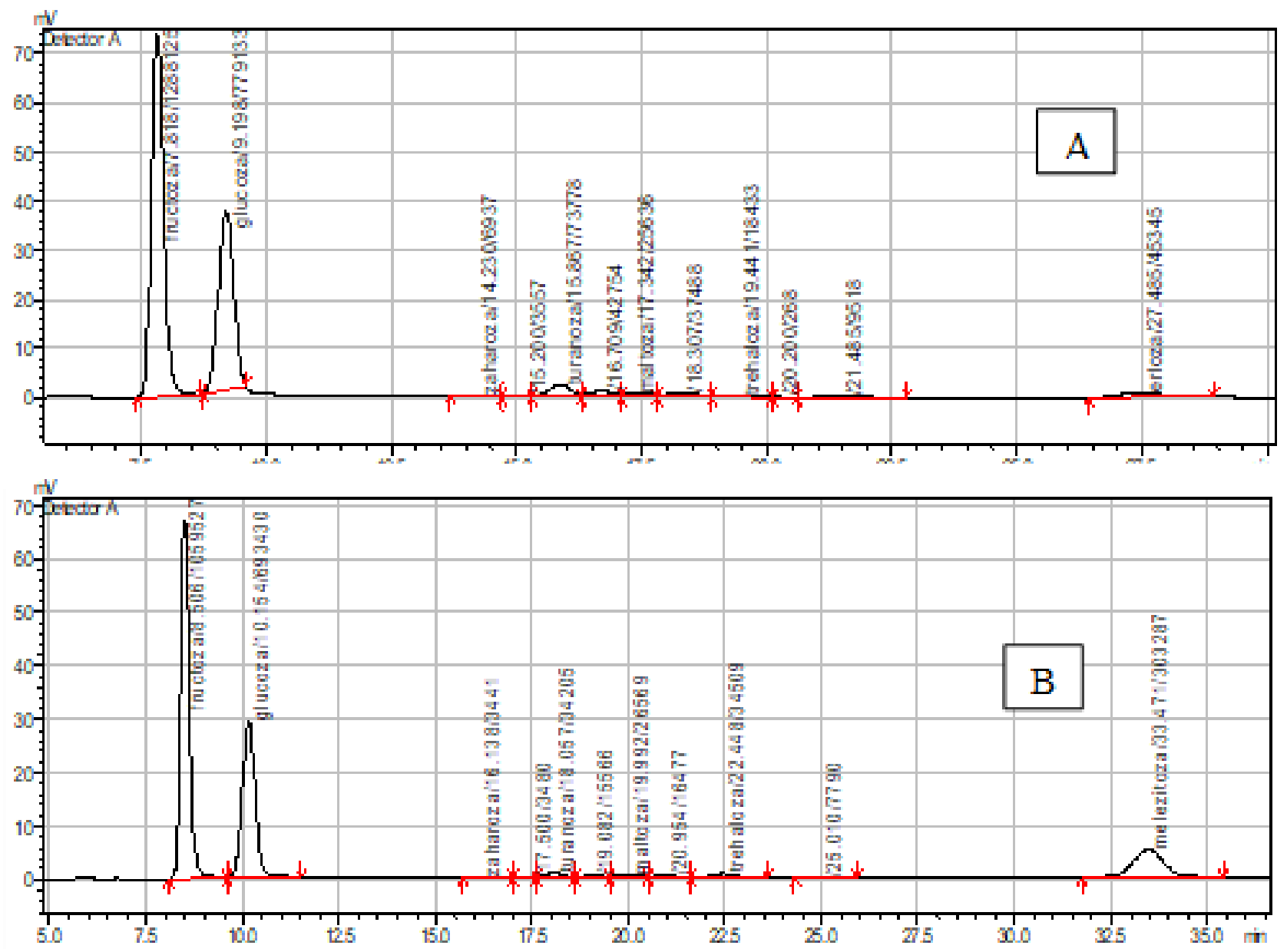

Figure 2. Sugar HPLC chromatogram of Acacia (A) and Honeydew honey samples (B)

\section{Conclusion}

The present study describes a validated approach of sugar content, diastase activity and HMF determinations in order to be used in honey authenticity determination. These are considered important methods to obtain accurate results in the authenticity process determination. The fact that low LOD and LOQ were established, give very good credentials for the methods, and also obtaining accurate results in the determinations. Overall conclusion is that several laboratory determinations need to be used in order to obtain data regarding honey authenticity.

Acknowledgments. This research did not receive any specific grant from funding agencies in the public, commercial, or not-for-profit sectors.

\section{References}

1. Afrin S, Forbes-Hernández TY, Cianciosi D, Pistollato F, Zhang J, Pacetti M, Amici A, Reboredo-Rodríguez P, Simal-Gandara J, Bompadre S, Quiles JL, Giampieri F, Battino M (2019). Strawberry tree honey as a new potential functional food. Part 2: Strawberry tree honey increases ROS generation by suppressing Nrf2-ARE and NF-kB signalling pathways and decreases metabolic phenotypes and metastatic activity in colon cancer cells. Journal of Functional Foods, 57: 477-487. doi: 10.1016/j. jff.2019.04.037.

2. Alvarez-Suarez JM, Giampieri F, Cordero M, Gasparrini M, Forbes-Hdernández TY, Mazzoni L, Afrin S, Beltrán-Ayala P, González-Paramás AM, Santos-Buelga C, Varela-Lopez A, Quiles JL, Battino M (2016). Activation of AMPK/Nrf2 signalling by Manuka honey protects human dermal fibroblasts against oxidative damage by improving antioxidant response and mitochondrial function promoting wound healing. Journal of Functional Foods, 25: 38-49. doi: 10.1016/j.jff.2016.05.008.

3. Alvarez-Suarez JS, Giampieri F, Battino M (2013). Honey as a Source of Dietary Antioxidants: Structures, Bioavailability and Evidence of Protective Effects Against 
Human Chronic Diseases. Current Medicinal Chemistry, 20: 621-638.

4. Aronne G, Giovanetti M, Sacchi R, De Micco V (2014). From Flower to Honey Bouquet: Possible Markets for the Botanical Origin of Robinia Honey. The Scientific World Journal, ID 547275, pp. 7. doi: 10.1155/2014/547275.

5. Bobiş O, Dezmirean DS, Moise AR (2018). Honey and Diabetes: The Importance of Natural Simple Sugars in Diet for Preventing and Treating Different Type of Diabetes. Oxidative Medicine and Cellular Longevity, ID 4757893, pp. 12. doi: 10.1155/2018/4757893.

6. Bobiş O, Moise AR, Ballesteros I, Sánchez Reyes E, Sánchez Durán S, Sánchez-Sánchez J, Cruz-Quintana S, Giampieri F Battino M, Alvarez-Suarez JM (2020). Eucalyptus honey: Quality parameters, chemical composition and healthpromoting properties. Food Chemistry, 325: 126870. doi: 10.1016/j.foodchem.2020.126870.

7. Bogdanov S, Jurendic T, Sieber R, Gallmann P (2008). Honey for nutrition and health: a review. Journal of the American College of Nutrition, 27: 677-689. doi: 10.1080/07315724.2008.10719745.

8. Bonta V, Mărghitaş LA, Stanciu O, Laslo L, Dezmirean D, Bobiş O (2008). High performance liquid chromatographic analysis of sugars in Transilvanian honeydew honey. Bulletin USAMVCN, 65: 229-232.

9. Bucekova M, Valachova I, Kohutova L, Prochazka E, Klaudiny J, Majtan J (2014). Honeybee glucose-oxidase - its expression in honeybee workers and comparative analysis of its content and $\mathrm{H}_{2} \mathrm{O}_{2}$-mediated antibacterial activity in natural honeys. Naturwissenchaften, 101: 661670. doi: 10.1007/s00114-014-1205-s.

10. Codex Alimentarius. Revised Codex Standard for Honey. Codex Stan. (2001). 12: 1982.

11. Council Directive 2001/110/EC relating to honey. Official Journal of European Commission L 164: 1-5.

12. Doner LW (1977). The Sugars of Honey - A Review. Journal of the Science of Food and Agriculture, 28: 443-456.

13. Eurachem CITAC Guide (2019). Metrological Traceability in Chemical Measurements. A Guide to achieving comparable results in chemical measurement. $2^{\text {nd }}$ Edition.

14. Eurachem CITAC Guide CG 4 (2012). Quantifying Uncertainty in Analytical Measurement. $3^{\text {rd }}$ Edition.

15. Eurachem Citac Guide CG4, (2000). Quantifying Uncertainty in Analytical Measurement, English edition, Second edition.

16. Fazalda A, Quraisiah A, Azlina MFN (2018). Antiulcer Effect of Honey in Nonsteroidal Anti-Inflammatory Drugs Induced Gastric Ulcer Model in Ragts: A Systematic Review. Evidence-Based Complementary and Alternativer Medicine, ID 7515692, pp. 123. doi: $10.1155 / 2018 / 7515692$.

17. Geana EI, Ciucure CT (2020). Establishing authenticity of honey via comprehensive Romanian honey analysis. Food Chemistry, 306: 125595 . doi: 10.1016/j. foodchem.2019.125595.

18. Harmonised Methods of the European Honey Commision (1997). Apidologie, extra issue 1-59.
19. Kamal MA and Klein P (2011). Determination of sugars in honey by liquid chromatography. Saudi Journal of Biological Sciences, 18: 17-21. doi: 10.1016/j. sjbs.2010.09.003.

20. Kocyigit A, Aydoglu G, Balkan E, Yenigun VB, Guler EM, Bulut HB, Koktasoglu F, Gören AC, Atayoglu AT (2019). Quercus pyrenaica Honeydew honey with high phenolic contents cause DNA damage, apoptosis and cell death through generation of reactive oxygen species in gastric adenocarcinoma cells. Integrative Cancer Therapies, 18: 1-12. doi: $10.1177 / 1534735419876334$.

21. Louvreaux J, Maurizio A, Vorwohl G (1978). Methods in melissopalynology. Bee World, 59: 139-157. doi: 10.1080/0005772x.1978.11097714.

22. Machado De-Melo AA, Almeida-Muradian LB, Sancho MT, Pascual-Máte A (2017).Composition and Properties of Apis mellifera Honey: a Review. Journal of Apicultural Research, 57: 5-37. doi: 10.1080/00218839.2017.1338444.

23. Mădaş NM, Mărghitaş LA, Dezmirean DS, Bobiş O, Ouissam A, Danthine S, Francis F, Haubruge E, Nguyen BK (2019a). Labelling Regulations and Quality Control of Honey Origin: A Review. Food Reviews International, 36: 215-240. doi: 10.1080/87559129.2019.1636063.

24. Mădaş NM, Mărghitaş LA, Dezmirean DS, Bonta V, Bobiş O, Fauconnier ML, Francis F, Haubruge E, Nguyen KB (2019b). Volatile Profile and Physico-Chemical Analysis of Acacia Honey for Geographical Origin and Nutritional Value Determination, Foods, 8: 445. doi: 10.3390/ foods8100445.

25. Mărghitaș LA, Dezmirean DS, Pocol CB, Ilea M, Bobis O, Gergen I (2010). The Development of a Biochemical Profile of Acacia Honey by Identifying Biochemical Determinants of its Quality. Notulae Botanicae Horti Agrobotanici 38: 84-90.

26. Megazyme International Ireland (2014). Diastase activity ( $\alpha$-Amylase) in honey. Assay Procedure K-AMZHY 04/05

27. Morales P, Haza AI (2013). Antiproliferative and apoptotic effects of Spanish honeys. Pharmacognosy Magasine, 9: 231-237. doi: 10.4103/0973-1296.113276.

28. Oroian M, Ropciuc S (2019). Romanian honey authentication using voltammetric electronic tongue. Correlation of voltammetric data with physic-chemical parameters and phenolic compounds. Computers and Electronics in Agriculture, 157: 371-379. doi: 10.1016/j. compag.2019.01.008.

29. Pauliuc D, Dranca F, Oroian M (2020). Antioxidant activity, total phenolic content, individual phenolics and physicochemical parameters suitability for Romanian honey authentication. Foods, 9, 306: 1-22. doi: 10.3390/ foods 9030306 .

30. Pereira Da Costa M, Conte AC (2014). Chromatographic Methods for the Determination of Carbohydrates and Organic Acids in Foods of Animal Origin. Comprehensive Reviews in Food Science and Food Safety, 14: 586-600. doi: 10.1111/1541-4337.12148.

31. Persano Oddo L, Piazza MG, Pulcini P (1999). Invertase activity in honey. Apidologie, 30: 57-65.

32. Persano-Oddo L, Baldi E, Accorti M (1990). Diastase activity in some unifloral honeys. Apidologie, 21: 17-24. 
33. Rady HA, Hemmaid KZ, Esmaeil NN, Eid MM, Elshat AA (2018). Sidr Kashmiry honey and its fractions induced apoptosis in hepatocellular carcinoma in vitro. Mediterranean Journal of Nutrition and Metabolism, 11: 343-351. doi: 10.3233/MNM-18209.

34. Samarghandian S, Afshari JT, Davoodi S (2011). Honey induces apoptosis in renal cell carcinoma. Pharmacognosy Magasine, 7: 46-52. doi: 10.4103/0973-1296.75901.

35. Sanz ML, Gonzalez M, de Lorenzo C, Sanz J, Martínez-Castro I (2005). A Contribution to the Differentiation between Nectar Honey and Honeydew Honey. Food Chemistry, 91: 313-317. doi: 10.1016/j.foodchem.2004.06.013.

36. Scepankova H, Saraiva JA, Estevinho LM (2017). Honey Health Benefits and Uses in Medicine. In J. M. AlvarezSuarez (Ed.), Bee Products - Chemical and Biological Properties (pp. 83-96). Springer, Cham doi: 10.1007/9783-319-59689-1_4.
37. Soares S, Amaral JS, Oliveira MBPP, Mafra I (2017). A Comprehensive Review on the Main Honey Authentication Issues: Production and Origin. Comprehensive Reviews in Food Science and Food Safety, 16: 1072-1100. doi: 10.1111/1541-4337.122787.

38. Vallianou NG, Gounari P, Skourtis A, Panagos J, Kazazis C (2014). Honey and its Anti-Inflammatory, Anti-Bacterial and Anti-Oxidant Properties. General Medicine (Los Angeles) 2: 132. doi: 10.4172/2327-5146.1000132.

39. Vranic D, Petronijevic R, Koricanac V, Djinovic Stojanovic J, Lilic S, Borovic B, Lukic M (2019). Evaluation of Serbian black locust honey quality parameters as a contribution to confirmation of its botanical origin. IOP Conf. Series: Earth and Environmental Science, 333: 012113. doi: $10.1088 / 1755-1315 / 333 / 1 / 012113$. 